\title{
RUSSIAN ACCENT IN BRAZILIAN PORTUGUESE AFFECTS THE PERCEPTION OF VOICE PLEASANTNESS BY BRAZILIANS
}

\author{
Sotaque Russo em Português Brasileiro Afeta a Percepção de \\ Agradabilidade de Voz por Brasileiros
}

Anna SMIRNOVA HENRIQUES

Pontifícia Universidade Católica de São Paulo

palestrasrussas@gmail.com

https://orcid.org/0000-0003-3011-372X

Sandra MADUREIRA

Pontifícia Universidade Católica de São Paulo

sandra.madureira.liaac@gmail.com https://orcid.org/0000-0001-8263-053X

\begin{abstract}
The field of foreign accents in Brazilian Portuguese is very poorly explored mainly in relation to perceptual impressions caused on listeners by foreign accents. The objective of this paper is to conduct a perceptual experiment to analyze the perception of voice pleasantness in relation to degrees of foreign accent. Our focus is on Russian accented Brazilian Portuguese. Despite the representativeness of the Russian community in Brazil, there are hardly any studies on Russian accented speech. To evaluate the perception of voice pleasantness in relation to the Russian accented speech, we have selected, from our database, speech samples in Brazilian Portuguese from 12 native Russian speakers and six Brazilians, all of them residing in São Paulo. The speech samples were incorporated into an online questionnaire. The analysis of the 129 answers given by the native Brazilian Portuguese speakers showed a strong negative correlation between the degree of Russian accent in Brazilian Portuguese and the degree of voice pleasantness. Experience of interaction with foreigners or knowledge of foreign languages, including Russian, did not influence the result. We conclude that higher degrees of Russian accented speech in Brazilian Portuguese affect the perception of speakers' characteristics by Brazilians in a negative way. KEYWORDS: Brazilian Portuguese as L2; Foreign accent; Sociophonetics; Speech perception.
\end{abstract}

RESUMO: O campo de sotaques estrangeiros em português brasileiro é pouco explorado, especialmente em relação à percepção de sotaques estrangeiros. O objetivo deste estudo é conduzir um experimento de 
percepção para analisar a percepção da agradabilidade de voz em relação ao grau de sotaque estrangeiro. O nosso foco é no sotaque russo em português brasileiro. Apesar de a comunidade russófona no Brasil ser bastante representada, a fala marcada pelo sotaque russo é pouco estudada. Para avaliar a percepção da agradabilidade de voz em relação ao grau de sotaque russo, selecionamos do nosso banco de dados amostras de fala em português brasileiro de 12 falantes de russo nativos e seis brasileiros, todos moradores de São Paulo. As amostras de fala foram incorporadas em um questionário disponível on-line. A análise de 129 respostas, dadas por falantes nativos de português brasileiro, demonstrou uma forte correlação negativa entre o grau de sotaque russo em português brasileiro e a percepção de agradabilidade de voz. A experiência de interação com estrangeiros ou de estudo de línguas estrangeiras, inclusive russo, não influenciou este resultado. Concluímos que os graus mais severos de sotaque russo em português brasileiro afetam a percepção de características pessoas dos falantes por brasileiros de maneira negativa. PALAVRAS-CHAVE: português brasileiro como L2; sotaque estrangeiro; sociofonética; percepção de fala.

\section{INTRODUCTION}

The term "accent" means a manner of pronunciation (LAVER, 1994). Regional accents are largely studied and well characterized in many languages, such as American and British English (ALFORD; STROTHER, 1990; HANANI; RUSSELL; CAREY, 2013; HUGHES; TRUDGILL; WATT, 2005), Spanish (CHIQUITO; QUESADA, 2014), French (DURAND; 2009; PALTRIDGE; GILES, 1984; WOEHRLING, 2009), Dutch (GRONDELAERS; HOUT; STEEGS, 2009), and Russian (KASATKIN, 2005; MIACHINSKAYA, 2016). This type of research also includes the issue of attitudes of native speakers towards regional varieties (ALFORD; STROTHER, 1990; CHIQUITO; QUESADA, 2014; MIACHINSKAYA, 2016; PALTRIDGE; GILES, 1984).

Brazil is investing efforts in the data collection for the Atlas Linguístico do Brasil $(A L i B)$, the Linguistic Atlas of Brazil (ANDRADE MOTA; MARCELINO CARDOSO, 2000; RAZKY, 2014); perception of the regional dialects by Brazilian Portuguese speakers from other regions has also been studied (LOPES et al., 2014; OUSHIRO; PARAFITACOUTO, 2017). The classical works of Labov emphasize the importance of studying the sociolinguistic aspects of accent variation (LABOV, 2001; 2006). The research currently conducted in Brazil also draws attention to the influence of social variables on accent: Oushiro (2017) mentions factors such as gender, age, education, social class, mobility, and origin of parents; for the internal migrants, she emphasizes the importance of age of 
arrival and length of residence (OUSHIRO, 2020).

Foreign accent is another important issue since both speech perception and production in L2 are affected by the L1 system of non-native speakers (LLISTERRI, 1995). The theories about phonological deafness (POLIVANOV, 1931) or the L1 phonological system functioning as a "filter" (TRUBETZKOY, 1939) exist since the first half of the 20th century. The contemporary models include the Speech Learning Model (SLM) (FLEGE, 1995; 2007); Perceptual Assimilation Model (BEST; TYLER, 2007); Phonological Permeability Hypothesis (CABRELLI AMARO; ROTHMAN, 2010); Articulatory Phonology (BROWMAN; GOLDSTEIN, 1989), among others. The crucial factors that affect the speech production in L2 are the quality and quantity of input in L2, and also the amount of L1 use (FLEGE, 1995, 2007). Factors such as age of L2 learning, length of residence, access to formal instruction, and motivation are considered to be secondary (MOYER, 2008; PISKE; MACKAY; FLEGE, 2001). Our focus here is not on the models explaining the phenomenon of accent in L2 or factors contributing to L2 accent severity, but on the perception studies of the foreign accent.

When listening to someone speaking, listeners are not only informed but impressed as well (BOLINGER, 1986). As Laver (1994) points out voice is an index of the biological, psychological and social characteristics of the speakers. Based on the segmental and prosodic choices the speakers make, listeners attribute paralinguistic (psychological conditions) as well as extralinguistic features (physical, social, regional and economic conditions). Relevant works on the index value of speech are Sapir (1920), Pittam (1995), Fonagy (2001), and Kreiman and Sidtis (2011), just to mention some. A discussion on the expressivity of speech productions can be found in Barbosa (2009) and Madureira, Fontes and Camargo (2019).

The first work that investigated judgments of bilingual speakers' speech productions in different languages was the one by Lambert et al. (1960). They recorded English and French guises of Canadian bilingual speakers and studied the perception of these productions by other participants who used only one school and primary social language: either English or French. The speech productions in both languages were judged in relation to the following speakers' qualities: the height, good looks, leadership capacity, sense of humor, intelligence, religiousness, self-confidence, dependability, entertainingness, kindness, ambition, sociability, character, and likability. The listeners did not know that the speech guises were produced by bilingual speakers, and that each speaker was listened to twice, once in each language. In the experiments by Lambert et al. (1960), the listeners who used English as their school and primary social language 
evaluated seven out of 14 traits more favorably for the English than for the French guises; the listeners who used mainly French evaluated more favorably the English guises for ten traits. In this experiment, the bilingual speakers did not have or were trained not to show a foreign accent. However, the idea that the same speaker could be perceived in different ways when he/she speaks different languages and the selection of judged traits greatly influenced the experimental design of the perception studies of the foreign accent.

Numerous studies demonstrated that non-native accented speech in English largely influence the perception of the foreign speakers' personal qualities and affect listeners' judgement of attitudes. Carlson and McHenry (2006) reported that the employability of the job applicants is affected not by the perception of their ethnicity, but by the degree of perceived accentedness of the applicants' speech. Lev-Ari and Keysar (2010) focused on the influence of accent on people's credibility: people judged trivial statements such as "Ants don't sleep" as less true when spoken by a non-native speaker. Russo, Islam and Koyuncu (2017) examined the impact of non-native accent on career advancement and career satisfaction. They concluded that speaking with a non-native accent may lead speakers to feel excluded and devalued at work, and even to assume an avoidance attitude towards work. Fuse, Navichkova and Alloggio (2018) asked monolingual and bilingual English speakers to rate four non-native accents (Spanish, Chinese, Russian, and Indian) on perceived intelligibility and perceived personal qualities (i.e., professionalism, intelligence, resourcefulness, empathy, and patience) necessary for speech-language pathologists. Greater perception of intelligibility was related to a positive perception of personal qualities such as professionalism, intelligence, and resourcefulness. Stigmatization of a foreign accent in English may affect millions of people who speak English as L2 and live in English-speaking countries (LEV-ARI; KEYSAR, 2010). However, the perception of a foreign accent in other languages is very poorly explored.

In Brazil, the field of Brazilian Portuguese as a Foreign Language is quite new, as very few Brazilian universities offer an undergraduate course in this area (FARNEDA, 2019). The research interests in the L2 acquisition/learning are focused on the learning foreign languages by Brazilians (CASTILHO, 2004; DINIZ DE FIGUEIREDO, 2018; SANT'ANNA, 2008); the attention to the Brazilian Portuguese acquisition/learning by foreigners has been limited even though Brazil has one of the largest migrant populations in South America (IOM World Migration Report, 2018, p. 80). Some reports describe the phonetic difficulties of foreigners learning Brazilian Portuguese, mainly native Spanish or English speakers. Foreigners have difficulties in discriminating open and close mid vowels 
(FEIDEN; ALVES; FINGER, 2014; GUIMARÃES, 2011; PEREYRON; ALVES, 2019; SMIRNOVA HENRIQUES et al., 2019), and do not produce devoicing, velarization, palatalization (CAMARGO, 2009), and nasalization correctly (CAMARGO, 2009; GUIMARÃES, 2011).

Our preliminary results obtained by a group of Audiology students who performed a perceptual analysis of homemade audio recordings received from 29 Russophone immigrants revealed the following features of the Russian accent in Brazilian Portuguese: (1) no distinction between open and close mid vowels; (2) devoicing of voiced consonants; (3) misproduction of nasalization features (VITORIANO DE ALMEIDA et al., 2018). However, even though some information about the foreign accent features in Brazilian Portuguese is available, no research in Brazil has been conducted until now to characterize in detail the sociolinguistic aspects of the foreign accent perception by Brazilians.

Native Russian speakers are quite well represented in the Slavic communities in Brazil. Exact numbers are uncertain, but, in the period between 2011 and 2016, Russians, as well as Poles, were between 15 nations that received the most work permits in Brazil (QUINTINO; TONHATI, 2017). The characterization of the migration profiles of 40 native Russian speakers from our database shows that $55 \%$ of them have migrated to Brazil for family reasons and 45\% for job (SMIRNOVA HENRIQUES et al., in press). In addition, another survey applied online to 103 native Russian speakers revealed that $56 \%$ of them learned Portuguese alone after moving to Brazil, and only $7 \%$ studied in a Brazilian language school (SMIRNOVA HENRIQUES et al., 2019). The opportunities to study Portuguese in Russia are very limited (AREFIEV, 2019), and this creates an influx of Russophone immigrants who acquire Brazilian Portuguese when living in Brazil without any special instruction. The same phenomenon is observed in Portugal (HEAD; SEMENOVA-HEAD, 2010). At the same time, the Russian speaking immigrants are highly educated and interested in taking part in research projects because they understand their importance (SMIRNOVA HENRIQUES et al., in press). In the present study, we have selected 12 native Russian speakers living in São Paulo and six Brazilian control speakers, and presented their speech samples of Brazilian Portuguese to 129 native Brazilians, São Paulo residents, to evaluate the perception of voice pleasantness in relation to degree of the Russian accent. The same speech samples were presented to 23 native Russian speakers fluent in Brazilian Portuguese. As far as we know, this perception test on the foreign accent in Brazilian Portuguese represents the first research of this type in Brazil. 


\section{METHODS AND RESULTS}

The experiment involved two kinds of tasks: 1) a production task performed by 12 native Russian speakers and six Brazilians: the speakers produced a semi-spontaneous speech in Brazilian Portuguese; 2) a perception task performed by 129 Brazilians and 23 native Russian speakers fluent in Brazilian Portuguese: the listeners judged the personal characteristics of the speakers based on their voice recordings.

\section{Subjects of the production task (speakers)}

The production task was performed by 12 native Russian speakers (six males and six females) and six Brazilians (three males and three females), all currently living in São Paulo. Their semi-spontaneous speech in Portuguese about their home city was recorded in a sound-isolated booth. These recordings were part of a more extended protocol that we applied for the collection of data for our database of Russian native speakers living in São Paulo (SMIRNOVA HENRIQUES et al., in press). This database includes only Russian speaking immigrants who moved to Brazil as adults and stayed as permanent residents. These 12 native Russian speakers were selected among 40 volunteers to guarantee the same number of males and females and equivalent representation of different degrees of Russian accented speech. The degree of Russian accent was evaluated by an experienced phonetician, native speaker of Brazilian Portuguese, using the scale from 1 (a very weak accent) to 5 (a very strong accent). The degree of the foreign accent in the speech of native Brazilians was assumed to have a value of 0 . All the Brazilian participants grew in São Paulo metropolitan area and did not present other regional accents.

All the participants filled a detailed questionnaire containing the following sections: (1) Personal data; (2) Migrant trajectory; (3) Current contact with the Russian language; (4) Self-evaluation of the proficiency level in Portuguese and exposure to Portuguese language; (5) General linguistic evaluation; (6) Phonetic difficulties (SMIRNOVA HENRIQUES et al., in press). They also signed informed consents. The study was approved by the Ethics Committee of Pontifícia Universidade Católica de São Paulo (CAAE 09079219.9.0000.5482).

\section{Stimuli}

The recordings of the subjects' semi-spontaneous speech in Portuguese about their home cities were edited to obtain small fragments from 6 to 14 seconds (Table 1). 
We did not establish the same fixed duration of the final recordings in order to keep the spontaneous aspects of the speech. All the words that have an affective value (as "bad", "good", "boring") were cut off in order not to influence listeners' judgements (PITTAM, 1994). The speech of the native Russian speakers was additionally edited to eliminate ungrammatical constructions and the wrong use of articles. The recordings obtained from 12 native Russian speakers and from six Brazilians were organized in a random order (see the subject random code in Table 1). Afterwards, the audio stimuli were embedded in videos with the same blue background and incorporated into a Google form.

TABLE 1 - LIST OF THE SPEAKERS WHO PROVIDED STIMULI FOR THE PERCEPTION TEST.

THE LIST IS ORGANIZED ACCORDING TO THE DEGREE OF FOREIGN ACCENT

\begin{tabular}{|c|c|c|c|c|c|c|}
\hline $\begin{array}{c}\text { Foreign } \\
\text { accent } \\
\text { degree* }\end{array}$ & $\begin{array}{c}\text { Subject } \\
\text { random } \\
\text { code }\end{array}$ & $\begin{array}{c}\text { Stimulus } \\
\text { duration, } \\
\mathbf{s}\end{array}$ & Gender & $\begin{array}{c}\text { Time of } \\
\text { residence } \\
\text { in Brazil }\end{array}$ & $\begin{array}{c}\text { Place of } \\
\text { birth }\end{array}$ & $\begin{array}{c}\text { Higher } \\
\text { education } * *\end{array}$ \\
\hline \multirow{6}{*}{0} & $\mathrm{R} 2$ & 6 & Female & whole life & Brazil & $\begin{array}{l}\text { Philology, } \\
\text { attending }\end{array}$ \\
\hline & $\mathrm{R} 4$ & 13 & Female & whole life & Brazil & Accounting \\
\hline & $\mathrm{R} 7$ & 13 & Male & whole life & Brazil & Philosofy \\
\hline & $\mathrm{R} 8$ & 13 & Male & whole life & Brazil & Music, Philology \\
\hline & R11 & 12 & Male & whole life & Brazil & Film studies \\
\hline & $\mathrm{R} 13$ & 15 & Female & whole life & Brazil & Journalism \\
\hline \multirow[b]{3}{*}{1} & R5 & 7 & Male & $>15$ & Russia & Area not known \\
\hline & R9 & 13 & Female & 8 & Georgia & Sociology \\
\hline & $\mathrm{R} 10$ & 9 & Male & 17 & Russia & Physics \\
\hline \multirow{2}{*}{2} & $\mathrm{R} 1$ & 14 & Female & 2.5 & Russia & Pharmacy \\
\hline & R17 & 13 & Female & 2.5 & Russia & Political science \\
\hline \multirow{3}{*}{3} & R3 & 12 & Male & 8 & Russia & Engineering \\
\hline & R12 & 11 & Male & 1 & Moldova & Not completed \\
\hline & $\mathrm{R} 15$ & 9 & Male & 6 & Russia & Economy \\
\hline \multirow{3}{*}{4} & R6 & 9 & Female & 0.25 & Ucrânia & Music \\
\hline & R14 & 9 & Female & 8 & Russia & Civil engineering \\
\hline & R16 & 10 & Female & 0.33 & Russia & Choreography \\
\hline 5 & R18 & 10 & Male & 2 & Russia & Philology \\
\hline
\end{tabular}

* the degree of the Russian accent was defined following the scale from 0 (native Brazilians) and 1 (a very weak accent) to 5 (a very strong accent).

** most participants have at least an undergraduate degree, so the area of education always means that they completed (or are attending, if mentioned) an undergraduate course. 


\section{Subjects of the perception task (listeners)}

The total number of the listeners who made judgments in the perception test was 184. Most participants were recruited through social networks, personal contacts and also through a mailing list of Brazilians who study the Russian language in São Paulo. The participants were asked to take part in an online speech perception test to contribute to the investigation about how voice quality affects the perception of personal characteristics.

They were informed that they would hear 18 voices, answer 16 questions about each voice, and also answer some sociodemographic questions about themselves. They were also informed that the whole protocol would take approximately 30 minutes to be answered. However, the participants were not instructed about the participation of foreigners in the test and the importance of the foreign accent for our study. All the personal questions about contact with foreigners and foreign languages were posed after the perception evaluation. For the data analysis, the participants were organized into four groups following the criteria of nationality, familiarity with foreigners and foreign languages, and place of residence (Table 2). All the nationalities other than Russian and Brazilian, and all the participants living in the states of Brazil other than São Paulo were eliminated from the present analysis. We kept only four Russian speakers that had already lived in São Paulo but currently were in Russia. After the filtering, the total number of the participants that suited the requirements described above was 152 .

\section{TABLE 2 - GROUPS OF LISTENERS WHO MADE THE JUDGMENTS IN THE ONLINE} PERCEPTION TEST

\begin{tabular}{|c|c|c|c|}
\hline Group & Native language & $\begin{array}{c}\text { Contact with foreigners and foreign } \\
\text { languages }\end{array}$ & $\begin{array}{c}\text { Number of } \\
\text { listeners }\end{array}$ \\
\hline 1 & Brazilian Portuguese & $\begin{array}{c}\text { No contact with foreigners or foreign } \\
\text { languages }\end{array}$ & 14 \\
\hline 2 & Brazilian Portuguese & $\begin{array}{c}\text { Some type of contact with foreigners or } \\
\text { foreign languages, but not Russian }\end{array}$ & 54 \\
\hline 3 & Brazilian Portuguese & $\begin{array}{c}\text { Having Russians friends or studying the } \\
\text { Russian language }\end{array}$ & 61 \\
\hline 4 & Russian & Fluent in Portuguese & 23 \\
\hline Total & & & 152 \\
\hline
\end{tabular}

All the data were collected in January and February, 2019. 


\section{Perceptual test procedures}

The listeners accessed the Google form containing the perception test at home or in other place of their convenience. They were asked to use headphones. First, they listened to 18 audio stimuli in Portuguese (see Stimuli section) and, one by one, evaluated each voice based on 16 criteria. The current work is focused on the essential criteria of voice pleasantness. However, the participants also evaluated the voices for expressivity and comprehensibility; and the respective speakers for humility, confidence, happiness, kindness, calmness, sociability, intelligence, age, beauty, height, education, financial situation and type of job. The pleasantness of the voice was evaluated following the scale with five options: (1) very pleasant; (2) pleasant; (3) not applicable; (4) unpleasant; (5) very unpleasant.

After the perception test, in the same questionnaire the participants were asked to give some personal information: gender; age; nationality; education; profession; their place of birth; the current city of residence; other cities where he/she had already lived in Brazil or abroad; the spoken/studied languages; whether they had contact with foreigners and, if so, the nationality of the foreigners; how good their day had been. The participants were also asked to continue the phrase in Portuguese "Foreigners in Brazil..." and to evaluate, following their perception and memory, without effectively going back to the recordings, how many voices from these 18 stimuli belonged to foreigners. No connections with Russians were mentioned to avoid that the participants shared information. The real number of foreigners' recordings was also not revealed until the end of the data collection.

\section{Analysis of the correlation between the Russian accent degree in Brazilian Portu- guese speech and the perception of voice pleasantness}

All the answers provided by the listeners who made judgments in the perception test were extracted from the Google form and transferred to an Excel spreadsheet. The listeners were separated into groups through Excel data filtering (Table2). The scale of voice pleasantness was reduced to three categories: pleasant (includes both "very pleasant" and "pleasant", initially suggested); not applicable; unpleasant (includes both "unpleasant" and "very unpleasant"). The number of the positive evaluations ("pleasant" category) was counted for each audio stimuli (Table 1) in each group of the participants (Table 2). The data in each group were normally distributed (the Kolmogorov-Smirnov test of normality, STANGROOM, 2020). The correlation between degree of the Russian accent in Brazilian Portuguese speech and the perception of voice pleasantness by Brazilians or 
Russians fluent in Brazilian Portuguese was evaluated through the Pearson's correlation coefficient (STANGROOM, 2020) (Table 3). The evaluations of voice pleasantness negatively correlated to the perceived degree of Russian accented speech for all groups of Brazilians, independently of their contact with foreigners and the Russian language, with the significance $p<0.005$ and the correlation coefficient -0.68 or stronger. In the group of Russians fluent in Brazilian Portuguese, the correlation between degree of the Russian accent and perception of voice pleasantness wasn't as strong as the one observed for Brazilians, but was also statistically significant with $\mathrm{p}<0.05$. There were no significant between-group differences (ANOVA: $F$-Stat $=0.21053, p=0.888774$, STANGROOM, 2020).

TABLE 3 - ANALYSIS OF THE CORRELATION BETWEEN THE DEGREE OF THE RUSSIAN ACCENT IN BRAZILIAN PORTUGUESE SPEECH AND THE PERCEPTION OF VOICE PLEASANTNESS. THE COLUMNS 3-6 SHOW THE PERCENTAGES OF THE NUMBER OF TIMES THAT THE VOICE OF THE RESPECTIVE SUBJECT WAS EVALUATED AS PLEASANT BY THIS GROUP OF PARTICIPANTS.

\begin{tabular}{|c|c|c|c|c|c|}
\hline \multirow{3}{*}{$\begin{array}{c}\text { Foreign } \\
\text { accent } \\
\text { degree* }^{*}\end{array}$} & \multirow{3}{*}{$\begin{array}{l}\text { Subject } \\
\text { random } \\
\text { code }\end{array}$} & \multicolumn{4}{|c|}{ Percentage of evaluations as "pleasant" in each group } \\
\hline & & \multicolumn{3}{|c|}{ Brazilian listeners (see Table 2) } & \multirow{2}{*}{$\begin{array}{c}\text { Russian } \\
\text { listeners, \% }\end{array}$} \\
\hline & & Group 1, \% & Group 2, \% & Group 3, \% & \\
\hline \multirow{6}{*}{0} & $\mathrm{R} 2$ & 64 & 85 & 82 & 78 \\
\hline & R4 & 79 & 78 & 85 & 61 \\
\hline & $\mathrm{R} 7$ & 71 & 78 & 66 & 87 \\
\hline & R8 & 79 & 65 & 62 & 65 \\
\hline & R11 & 79 & 74 & 64 & 52 \\
\hline & R13 & 86 & 83 & 79 & 83 \\
\hline \multirow{3}{*}{1} & R5 & 93 & 87 & 74 & 100 \\
\hline & R9 & 93 & 85 & 89 & 91 \\
\hline & R10 & 64 & 67 & 62 & 83 \\
\hline \multirow{2}{*}{2} & R1 & 50 & 52 & 62 & 65 \\
\hline & R17 & 86 & 87 & 90 & 78 \\
\hline \multirow{3}{*}{3} & R3 & 57 & 78 & 74 & 83 \\
\hline & $\mathrm{R} 12$ & 21 & 43 & 33 & 52 \\
\hline & R15 & 29 & 33 & 44 & 35 \\
\hline \multirow{3}{*}{4} & R6 & 50 & 37 & 38 & 26 \\
\hline & R14 & 21 & 22 & 39 & 22 \\
\hline & $\mathrm{R} 16$ & 21 & 48 & 52 & 35 \\
\hline \multirow[t]{3}{*}{5} & $\mathrm{R} 18$ & 21 & 39 & 44 & 70 \\
\hline & $\begin{array}{c}\text { Correlation } \\
\text { coefficient }\end{array}$ & -0.81 & -0.7749 & -0.6897 & -0.5645 \\
\hline & $\mathrm{p}$ & 0.000038 & 0.000186 & 0.001903 & 0.014771 \\
\hline
\end{tabular}

* the degree of the Russian accent was defined following the scale from 0 (native Brazilians) and 1 (a very weak accent) to 5 (a very strong accent) 


\section{DISCUSSION AND CONCLUSIONS}

In the current work, we analyze the results of the perception test designed to evaluate if the perception of the voice pleasantness by Brazilian listeners is correlated with the degree of the Russian accent. We have observed a strong negative correlation between the degree of the Russian accent and a number of evaluations of the voice as "pleasant". The correlation coefficient was stronger than -0.68 in all three groups of Brazilians, independently on their contact with foreigners and foreign language studies, including Russian. There is a quite big group of Brazilians who have Russian friends or study the Russian language ( $n=61$ ), due to the participation of Brazilian students who study Russian in Clube Russo Priviet in São Paulo. Even though the sizes of the groups of Brazilians who study other languages than Russian and study Russian are quite similar (Table 2), the correlation coefficients between degree of the Russian accent and a number of evaluations of the voice as "pleasant" in both groups are close (Table 3). The fact that the perception of voice pleasantness by native Russian speakers is also affected by the presence of the Russian accent in non-native language is not something new: Abramova (2013) has shown that Russian listeners related the stronger degree of Russian accent in English to the less positive speakers' characteristics. In the same experiment, listeners native in mainstream Received Pronunciation (RP) English related a stronger degree of the Russian accent in English to the education level of the speakers, but not to the personal characteristics. The influence of cultural components on the perception of the foreign-accented speech needs to be further investigated.

Here we conclude that the Russian accent in Brazilian Portuguese affects the perception of the speaker characteristics by Brazilians and native Russian speakers fluent in Brazilian Portuguese, and plan the following as the next steps:

1) to extend our analysis to the perception of other personal characteristics of the same speakers, evaluated in the current experiment, and to develop a strategy for the multifactorial statistical analysis through R (R CORE TEAM, 2020). The multifactorial statistical analysis would be also helpful to elucidate if the experience of learning other languages or contact with Russian people influences the evaluation of Russian-accented speakers' characteristics by Brazilians, and if the evaluations of the same speakers produced by listeners native in Russian would show a different profile. We consider to follow the strategies that have already been applied for understanding the variation of pronunciation within the group of native Brazilian Portuguese speakers from São Paulo (OUSHIRO, 2015) or for evaluating the perception of social, psychological, physical, 
cultural and speech valence features, based on listening to the speech of Caiçara community members, in a test answered by native Brazilian Portuguese speakers from other regional communities (TANURI, 2020);

2) considering that all the stimuli recorded by the native Russian speakers were produced not only in Portuguese but also in Russian, following exactly the same tasks (SMIRNOVA HENRIQUES et al., in press), we intend to analyze how the same bilingual subject is perceived by Brazilians when he/she speaks Russian-accented Brazilian Portuguese and by Russian native speakers when he/she speaks Russian. The voice perception depends on the vocal profile (KREIMAN \& SIDTIS, 2011; PITTAM, 1994), and the analysis of the data obtained in both languages would allow to separate the vocal quality from the foreign accent influences. The speakers' characteristics evaluated in equivalent ways by guises performed in both languages are influenced by the vocal quality itself. As far as we know, the tests evaluating the perception of bilingual speakers' personal characteristics through the samples of both his/her languages, in L1 and L2, are not common. The classic work of Lambert et al. (1960) involved bilinguals who did not have a foreign accent in both English and French. In our case, the speech of the native Russian speakers in Brazilian Portuguese is foreign-accented, and their native speech in Russian could be subjected to the phenomenon of attrition (BARDOVI-HARLIGAND; STRINGER, 2010; SCHMID, KÖPKE, 2007). We did not analyze the phonetic attrition profiles. However, we have recently described that some of the native Russian speakers from our databank replace native intonation patterns in Russian by those used in Brazilian Portuguese (KACHKOVSKAIA et al., in press). So, we also will be able to evaluate if the evaluation of speakers' characteristics by listeners native in Russian is influenced by the attrition profile in the Russian speech of the speakers.

The perception tests on a foreign-accented speech open a new discussion space in the fields of sociolinguistics, second language acquisition, and bilingualism studies, especially when we expand the analysis beyond the relatively well studied Englishspeaking countries. The knowledge about the effects that "sounding foreign" produces on listeners has not only linguistic importance (MOYER, 2013), but could also foster the development of the language policies, urgently needed in Brazil.

\section{ACKNOWLEDGMENTS}

Dr. Smirnova Henriques is supported by a postdoctoral fellowship PNPD/CAPES (Programa Nacional de Pós-Doutorado da Coordenação de Aperfeiçoamento de Pessoal 
de Nivel Superior). We also thank Dr. Mario Augusto de Souza Fontes from Departmento de Ciências da Lingugem e Filosofia da Pontifícia Universidade Católica de São Paulo, Dr. Lívia Oushiro from Instituto de Estudos da Linguagem da Universidade Estadual de Campinas and Dr. Anatoli Iambartsev from Instituto de Matemática e Estatística da Universidade de São Paulo for helpful discussions about future strategies to be applied on data analysis. 


\section{REFERENCES:}

ABRAMOVA, I. E. Foneticheskaja variativnost'v uslovijah iskusstvennogo bilingvizma [Phonetic variation in the conditions of artificial bilinguialism]. 2013. Doctoral thesis (Language Theory) - Saint Petersburg State University, Saint Petersburg, Russia. Available from: $<$ https://www.dissercat.com/content/foneticheskaya-variativnost-vusloviyakh-iskusstvennogo-bilingvizma>. access on 13 Aug. 2020.

ALFORD, R. L.; STROTHER, J. B. Attitudes of Native and Nonnative Speakers toward Selected Regional Accents of U.S. English. TESOL Quarterly, v. 24, n. 3, p. 479-495, 1990. Available from <https://doi.org/10.2307/3587231>. access on 13 Aug. 2020.

ANDRADE MOTA, J.; MARCELINO CARDOSO, S. A. Dialetologia brasileira: o atlas lingüístico do Brasil. Revista da ANPOLL, v. 1, n. 8, p. 41-57, 2000. Disponível em: $<$ https://revistadaanpoll.emnuvens.com.br/revista/article/view/349>. Acesso em 10 ago. 2020.

AREFIEV, A. Sotrudnichestvo Rossii i Portugalii v oblasti obrazovaniya i vzaimnoe izuchenie iazykov [Cooperation between Russia and Portugal in the education field and mutual learning of languages. In Russian]. In: NIKUNLASSI, A.; PROTASSOVA, E. (Eds.) Slavica Helsingiensia 52. Russian Linguage in the Multilingual World. Helsinki, University of Helsinki, 2019. p. 123-133. Available from: $<$ https://blogs.helsinki.fi/slavica-helsingiensia/slavica-helsingiensia-52/>. access on 13 Aug. 2020.

BARBOSA, P. A. Detecting Changes in Speech Expressiveness in participants of a radio program. In: INTERSPEECH, 10., 2009, Brighton, United Kingdom. Proceedings [...]. Brighton: International Speech Communications Association, 1, 2009. p. 2119-2122.

BARDOVI-HARLIGAND, K.; STRINGER, D. Variables in second language attrition. Studies in Second Language Acquisition, v. 32, n. 1, p. 1-45, 2010. doi:10.1017/ S0272263109990246.

BEST, C. T.; TYLER, M. D. Nonnative and second-language speech perception: Commonalities and complementarities. In: MUNRO, M.; BOHN, O. S. (Eds.). Second language speech learning. Amsterdam: John Benjamins, 2007. p. 13-34.

BOLINGER, D. Intonation and its Parts. Melody in Spoken English. Stanford: Stanford University Press, 1986.

BROWMAN, C.; GOLDSTEIN, L. Articulatory gestures as phonological units. Phonology, 6, 1989. p. 201- 251. 
CABRELLI AMARO, J.; ROTHMAN, J. On L3 acquisition and phonological permeability: A new test case for debates on the mental representation of non-native phonological systems. IRAL, International Review of Applied Linguistics in Language Teaching, v. 48, p. 275-296, 2010.

CAMARGO, V. S. Traços fonético-fonológicos do Português para falantes do espanhol e do inglês: segmentos dificultadores para a aquisição do Português Brasileiro. 2009. Dissertação (Mestrado em Letras) - Faculdade de Filosofia, Letras e Ciências Humanas, Universidade de São Paulo, São Paulo. Disponível em: $<$ https://www.teses.usp.br/teses/disponiveis/8/8142/tde-01022010-143929/pt-br.php>. Acesso em 13 ago. 2020.

CARLSON, H.; MCHENRY, M. A. Effect of accent and dialect on employability. Journal of Employment Counseling, v. 43, n. 2, p. 70-83, 2006.

CASTILHO, F. A. R. O. Questões de pronúncia em língua inglesa: fatores desencadeantes da percepção do sotaque do falante brasileiro de língua inglesa em relação à produção dos sons fricativos alveolalabires. 2004. Dissertação (Mestrado em Linguística Aplicada e Estudos de Linguagem) - PEPG de Linguística Aplicada e Estudos de Linguagem, Pontifícia Universidade Católica de São Paulo, São Paulo. Disponível em: $<$ https://www.pucsp.br/liaac/download/fabiola.pdf>. Acesso em 10 ago. 2020.

CHIQUITO,A.B.; QUESADA, M. Á.(Eds.).Actitudes lingüísticas delos hispanohablantes hacia el idioma español y sus variantes. Bergen Language and Linguistic Studies (BeLLS), 5, 2014. Available from <https://bells.uib.no/index.php/bells/issue/view/161>. access on 13 Aug. 2020.

DINIZ DE FIGUEIREDO, E. H. Second language acquisition in Brazil since the social turn. Rev. bras. linguist. apl., v. 18, n. 1, 2018. DOI: 10.1590/1984-6398201812420.

DURAND, J. Essai de panorama critique des accents du midi. In: BARONIAN, L.; MARTINEAU, F. (Eds.). Le français, d'un continent à l'autre : Mélanges offerts à Yves Charles Morin. Collection Les Voies du français. Québec: Presses de 1'Université Laval, 2009. p. 123-170.

FARNEDA, E.S. Português língua de acolhimento - cursos de extensão e capacitação para professores de português língua materna: abordagens e práticas. In: GONÇALVES MENDES, R. M. (Ed.) Ensino e Aprendizagem de Linguas Adicionais em Foco. Boavista Press, Roosevelt, 2019. p. 53-64.

FEIDEN, J. A.; ALVES, U. K.; FINGER, I. O efeito da anterioridade e da altura na identificação das vogais médias altas e médias baixas do Português Brasileiro por falantes de espanhol. Letras de Hoje, v. 49, p. 85-94, 2014. 
FLEGE, J. E. Language contact in bilingualism: Phonetic system interactions. In: COLE, J.; HUALDE, J. I. (Eds.) Papers in Laboratory Phonology 9, 9. ed. Berlin: Mouton de Gruyter, 2007. p. 353-382.

FLEGE, J. E. Second-language Speech Learning: Theory, Findings, and Problems. In: STRANGE, W. (Ed.) Speech Perception and Linguistic Experience: Issues in Crosslanguage Research. Timonium, MD: York Press, 1995. p. 229-273.

FÓNAGY, I. Languages within Language: an Evolutive Approach. Amsterdam: John Benjamins, 2001.

FUSE, A.; NAVICHKOVA, Y.; ALLOGGIO, K. Perception of intelligibility and qualities of non-native accented speakers. J Commun Disord., v. 71, p.37-51, 2018. Available from $<$ https://doi.org/10.1016/j.jcomdis.2017.12.006>. access on 13 Aug. 2020.

GRONDELAERS, S.; HOUT, R. van; STEEGS, M. Evaluating Regional Accent Variation in Standard Dutch. Journal of Language and Social Psychology, v. 29, n. 1, p. 101-115, 2010. Available from <https://doi.org/10.1177/0261927X09351681>. access on 10 Aug. 2020.

GUIMARÃES, F. I. S. Aquisição do português como L2 por falantes de espanhol: uma experiência com o modelo de ontogenia. 2011. Dissertação (Mestrado em Filologia e Língua Portuguesa) - Faculdade de Filosofia, Letras e Ciências Humanas, Universidade de São Paulo. Disponível em: $<$ https://www.teses.usp.br/teses/disponiveis/8/8142/tde-21052012-093406/pt-br.php>. Acesso em 10 ago. 2020.

HANANI, A.; RUSSELL, M. J.; CAREY, M. J. Human and computer recognition of regional accents and ethnic groups from British English speech. Computer Speech \& Language, v. 27, n. 1, p. 59-74, 2013. Available from $<$ https://doi.org/10.1016/j.csl.2012.01.003>. access on 13 Aug. 2020.

HEAD, B. F.; SEMENOVA-HEAD, L. Problemas na aprendizagem da pronúncia portuguesa entre falantes adultos de russo. Cadernos de Comunicação e Linguagem, v. 2, p. 13-33, 2010. Disponível em: <https://bdigital.ufp.pt/handle/10284/2957>. Acesso em 13 ago. 2020.

HUGHES, A.; TRUDGILL, P.; WATT, D. English Accents and Dialects: An Introduction to Social and Regional Varieties of English in the British Isles. 4. ed. London: Hodder Arnold, 2005.

IOM World Migration Report 2018, UN, New York, 2018. Available from: $<$ https://doi.org/10.18356/f45862f3-en>. access on 10 Aug. 2020. 
KACHKOVSKAIA, T. V.; SKRELIN, P. A.; SMIRNOVA HENRIQUES, A.; MADUREIRA, S. Gradual changes in native intonation system: the case of Russians living in Brazil. Accepted for the presentation on $49^{\mathrm{TH}}$ INTERNATIONAL SCIENTIFIC PHILOLOGICAL CONFERENCE, Saint Petersburg, 2020.

KASATKIN, L. L. Russkaia Dialektologiia [Russian Dialectology]. Moscow: Akademia, 2005.

KREIMAN, J.; SIDTIS, D. Foundations of voice studies: An interdisciplinary approach to voice production and perception. Boston: Wiley-Blackwell, 2011.

LAVER, J. Principles of phonetics. Cambridge: Cambridge University Press, 1994.

LABOV, W. Principles of Linguistic Change. Vol. 2: Social Factors. Malden: Blackwell, 2001.

LABOV, W. The social stratification of English in New York City. New York: Cambridge University Press, 2006.

LAMBERT, W.; HODGSON, R.; GARDNER, R.; FILLENBAUM. S. Evaluational reactions to spoken languages. The Journal of Abnormal and Social Psychology, v. 60, n. 1, p. 44-51, 1960.

LEV-ARI, S.; KEYSAR, B. Why don't we believe non-native speakers? The influence of accent on credibility. J Exp Soc Psychol., v. 46, p. 1093-1096, 2010. Available from $<$ https://doi.org/10.1016/j.jesp.2010.05.025>. access on 13 Aug. 2020.

LLISTERRI, J. Relationships between speech production and speech perception in a second language. In: INTERNATIONAL CONGRESS OF PHONETIC SCIENCES, 13., Stockholm, 1995. Proceedings [...]. Stockholm, 1995. p. 92-99.

LOPES, L. W.; LIMA, I. L B.; SILVA, E.; ALMEIDA, L. N. A.; ALMEIDA, A. A. F. Preferências dos ouvintes em relação ao sotaque regional em contexto formal e informal de comunicação. Revista CEFAC, v. 16, p. 949-956, 2014.

MADUREIRA, S.; FONTES, M. A. S.; CAMARGO, Z. Sound symbolism, speech expressivity and crossmodality. Symbolisme phonétique et transmodalité, Signifiances (Signifying), v. 3 (1), p. 98-113, 2019. Available from $<$ https://doi.org/10.18145/signifiances.v3i1.234>. access on 10 Aug. 2020.

MOYER, A. Input as a Critical Means to an End: Quantity and Quality of L2 Experience in Phonological Attainment. In: YOUNG-SCHOLTEN, M.; PISKE, T. (Eds.). Input matters in SLA. Bristol - Buffalo - Toronto: Multilingual Matters, 2008. p. 159-174. 
MOYER, A. Foreign Accent: The Phenomenon of Non-native Speech. Cambridge: Cambridge University Press, 2013. p. 102.

MIACHINSKAIA, E. I. Dialektnye stereotipy v predstavlenii nositelei russkogo normativnogo iazyka [Dialect stereotypes of native Russian speakers using the normative language]. Russkaia ustnaia rech, n. 2, 2016. p. 186-191.

OUSHIRO, L. Identidade na pluralidade: avaliação, produção e percepção linguística na cidade de São Paulo. 2015. Tese (Doutorado em Linguística) - Universidade de São Paulo, São Paulo.

OUSHIRO, L. Fatores sociais na coesão dialetal. In: VASCONCELOS, M. L. M. C.; BATISTA, R. O.; PEREIRA, H. B. (Orgs.). Estudos linguísticos: língua, história, ensino. 1. ed. São Paulo: Editora Mackenzie, v. 1, 2017. p. 47-63.

OUSHIRO, L. Contrasting Age of Arrival and Length of Residence in Dialect Contact. University of Pennsylvania Working Papers in Linguistics, v. 25, n. 2, Article 10, 2020. Available from <https://repository.upenn.edu/pwpl/vol25/iss2/10>. access on 10 Aug. 2020 .

OUSHIRO, L.; PARAFITA-COUTO, M. C. Old variables, new meanings: resignification of rural speech variants in São Paulo's urban ecology. In: SMAKMAN, D.; HEINRICH, P. (Org.). Urban sociolinguistics: The City as a Linguistic Process and Experience. 1ed. New York: Routledge, v. 1, 2017. p. 58-76.

PALTRIDGE, J.; GILES, H. Attitudes towards speakers of regional accents of French: Effects of regionality, age and sex of listeners. Linguistische Berichte, n. 90, p. 71-85, 1984.

PEREYRON, L.; ALVES, U. K. Descrição acústica das vogais tônicas do espanhol rioplatense e de uma variedade do português do sul do brasil de monolíngues e bilíngues: uma discussão dinâmica sobre desenvolvimento linguístico. Revista Linguística, v. 35, p. 103-127, 2019. Disponível em: $<$ https://dialnet.unirioja.es/servlet/articulo?codigo=7013060>. Acesso em 13 ago. 2020.

PISKE, T.; MACKAY, I.; FLEGE, J. E. Factors affecting degree of foreign accent in an L2: A review. Journal of Phonetics, v. 29, p. 191-215, 2001. Available from: $<$ https://doi.org/10.1006/jpho.2001.0134>. access on 13 Aug. 2020.

PITTAM, J. Voice in Social Interaction: An Interdisciplinary Approach. Thousand Oaks: SAGE Publications, Inc., 1994. Available from: $<$ http://dx.doi.org/10.4135/9781483327105>. access on 10 Aug. 2020. 
POLIVANOV, E. D. A percepção dos sons de uma língua estrangeira. In: TOLEDO, D. (Org.) Círculo Linguístico de Praga: estruturalismo e semiologia. Porto Alerge: Editora Globo, p. 113-128, 1978 [1931].

QUINTINO, F.; TONHATI, T. Uma análise das autorizações de trabalho concedidas a estrangeiros pela Coordenação Geral de Imigração (CGIg 2011-2016). In: A inserção dos imigrantes no mercado de trabalho brasileiro. Relatório anual 2017. Série Migrações. Observatório das Migrações Internacionais; Ministério do Trabalho/ Conselho Nacional de Imigração e Coordenação Geral de Imigração. Brasília, DF: OBMigra, 2017. p. 16-33. Disponível em: <http://obmigra.mte.gov.br/index.php/publicacoes-obmigra $>$. Acesso em 13 ago. 2020.

R CORE TEAM (2013). R: A language and environment for statistical computing. $\mathrm{R}$ Foundation for Statistical Computing, Vienna, Austria. Available from: $<$ http://www.R-project.org/>. access on 10 Aug. 2020.

RAZKY, A. A dimensão sociodialetal do léxico no projeto Atlas Linguístico do Brasil. Signum: Estudos da Linguagem, v. 16, n. 2, p. 247-270, 2014. doi:10.5433/22374876.2013v16n2p247

RUSSO, M.; ISLAM, G; KOYUNCU, B. Non-native accents and stigma: How selffulfilling prophesies can affect career outcomes. Human Resource Management Review, v. 27, p. 507-520, 2017. Available from <https://doi.org/10.1016/j.hrmr.2016.12.001>. access on 13 Aug. 2020.

SANT'ANNA, M. R. de. A pronúncia das consoantes inglesas em final de vocábulo por falantes brasileiros. 2008. Tese (Doutorado em Letras) - Faculdade de Filosofia, Letras e Ciências Humanas, Universidade de São Paulo, São Paulo. Disponível em: $<$ https://www.teses.usp.br/teses/disponiveis/8/8139/tde-03022009-113509/publico/ TESE_MAGALI_ROSA_SANTANNA.pdf $>$. access on 13 Aug. 2020.

SAPIR, E. Speech as a Personality Trait. American Journal of Sociology, v. 32, p. 892905, 1927.

SCHMID, M.; KÖPKE, B. Bilingualism and attrition. In: KÖPKE, B.; SCHMID, M. S.; KEIJZER, M.; DOSTERT, S. (Eds.). Language Attrition: theoretical perspectives. Studies in Bilingualism 33. Amsterdam: John Benjamins, 2007. p. 1-7.

SMIRNOVA HENRIQUES, A.; DE SOUZA FONTES, M. A.; SKRELIN, P. A.; KACHKOVSKAIA, T. V.; RUSEISHVILI, S.; BORREGO, M. C.; ZULETA, P. P. B.; PICCOLOTTO FERREIRA, L.; MADUREIRA S. Russian immigrants in Brazil: to understand, to be understood. Cadernos de Linguística, in press. 
SMIRNOVA HENRIQUES, A.; SKRELIN, P. A.; EVDOKIMOVA, V. V.; KACHKOVSKAIA, T. V.; BORREGO, M. C.; PICCOLOTTO FERREIRA, L.; PICCIN BERTELLI ZULETA, P.; RUSEISHVILI, S.; MADUREIRA, S. The perception of Brazilian Portuguese open and close mid vowels by native Russian speakers. JoSS, v. 8 , n. 2, p. 59-84, 2019.

STANGROOM, J. The Kolmogorov-Smirnov Test of Normality Calculator. Social Science Statistics. Available from: $<$ https://www.socscistatistics.com/tests/kolmogorov/ default.aspx $>$. access on 10 Aug. 2020.

STANGROOM, J. One-Way ANOVA Calculator. Social Science Statistics. Available from <https://www.socscistatistics.com/tests/anova/default2.aspx $>$. access on 13 Aug. 2020 .

STANGROOM, J. Pearson Correlation Coefficient Calculator. Social Science Statistics. Available from <https://www.socscistatistics.com/tests/pearson/default2.aspx $>$. access on 10 Aug. 2020.

TANURI, M. A. F. A percepção de atitudes em relação ao sotaque de comunidade caiçara do Litoral Norte de São Paulo. 2020. Tese (Doutorado em Linguística) - Pontifícia Universidade Católica de São Paulo, São Paulo.

TRUBETZKOY, N. Principles of Phonology. Translated by BALTAXE, C. A. Berkeley: University of California Press, 1969 [1939].

VITORIANO DE ALMEIDA, K.; BORREGO, M. C.; GOBBO, R.; BASÍLIO, M.; SMIRNOVA HENRIQUES, A.; ZULETA, P. P. B.; RUSEISHVILI, S.; PICCOLOTTO FERREIRA, L. Produção oral de falantes russos que aprendem português brasileiro. In: XXVI CONGRESSO BRASILEIRO DE FONOAUDIOLOGIA, 2018, Curitiba. Anais [...]. Curitiba: Universidade Tuiuti do Paraná, 2018. p. 10365. Disponível em: $<$ https://www.sbfa.org.br/portal/anais2018/trabalhos_select.php?tt=Busca\&id_ artigo $=10365>$. access on 13 Aug. 2020.

WOEHRLING, C. Accents régionaux en français: perception, analyse et modélisation à partir de grands corpus. 2009. Thesis ( $\mathrm{PhD}$ in Sciences) - École Doctorale d'Informatique, Université Paris Sud - Paris XI, Paris. Available from $<$ https://tel.archives-ouvertes.fr/tel-00617248/>. access on 10 Aug. 2020. 